The Effects of Oregano Oil (Origanum onites L.) on the Growth Performance and Some Blood Parameters of Holstein Friesian Calves

\author{
Muhammet Hanifi SELVİ1 1 (iD), İbrahim TAPKI2 iD \\ ${ }_{1,2}$ Hatay Mustafa Kemal University, Agriculture Faculty, Department of Animal Science, 31060 Antakya-Turkey \\ ${ }^{1}$ https://orcid.org/0000-0002-9785-9174, ${ }^{2}$ https://orcid.org/0000-0002-4552-6941 \\ $\bowtie:$ mselvi1453@gmail.com
}

\begin{abstract}
This study was conducted on 44 newborn Holstein Friesian calves raised in a private farm in Hatay province, Turkey. The calves were divided into two groups; the first group (control group) was fed only with milk replacer and the second group was fed with milk replacer added $893 \mathrm{mg}$ oregano oil (oregano oil group) from the fourth day after calving. The amount of milk replacer offered to the calves was $10 \%$ of their weekly live weights. The calves were weaned when they consumed $800 \mathrm{~g}$ concentrate feed daily for three consecutive days. Weaning age and daily live weight gains for control and oregano oil group calves were found as $68.6 \pm 4.45,67.7 \pm 4.62$ days and $0.300 \pm$ $0.09,0.400 \pm 0.011 \mathrm{~kg}$, respectively. The mean consumption of milk replacer, hay and concentrate feed of calves for the control and orageno oil calves were found as $327.7 \pm 42.17,331.0 \pm 49.40$ liters; $13.25 \pm 3.025,15.23 \pm 3.682 \mathrm{~kg}$ and $19.97 \pm 4.186,22.37 \pm 5.709 \mathrm{~kg}$, respectively. The average initial hay, and concentrate feed consuming ages and diarrhea days for the control and oregano oil groups were determined as $10.6 \pm 0.29,9.5 \pm 0.28$ and $3.1 \pm 0.111,1.9 \pm 0.073$ days The initial hay and concentrate feed consuming ages were the same in both groups. According to the results of the study, more research is needed to evaluate the optimal dosing of oregano oil.
\end{abstract}

Research Article

$\begin{array}{ll}\text { Article History } & \\ \text { Received } & : 01.04 .2019 \\ \text { Accepted } & : 16.05 .2019\end{array}$

Keywords

Milk replacer

Oregano oil

Growth

Performance

Blood

Diarrhea

\title{
Siyah Alaca Buzağılarda Kekik Yağının (Origanum onites L.) Buzağıların Gelişim Performansı ve Bazı
} Kan Parametreleri Üzerine Etkisi

\section{ÖZET}

Bu çalışma, Hatay ilinde özel bir işletmede yetiştirilen 44 baş yeni doğmuş Siyah Alaca ırkı buzağı üzerinde yürütülmüştür. Buzağılar 2 gruba ayrılmış olup, birinci gruba (kontrol grubu), 4. günden itibaren sadece buzağı maması, ikinci gruba (kekik yağı grubu) ise buzağ mamasına ilaveten $893 \mathrm{mg}$ kekik yağı ilave edilmiştir. İçirilen mama miktarı, buzağıların haftalık canlı ağırlıklarının \% 10’u kadar hesaplanmıştır. Üç gün üst üste 800 gr kesif yem tüketen buzağılar mamadan kesilmiştir. Kontrol ve kekik yağı grubu buzağı gruplarında mamadan kesim yaşı ile günlük canlı ağırlık artışı sırasıyla; $68.6 \pm$ $4.45,67.7 \pm 4.62$ gün ve $0.300 \pm 0.09,0.400 \pm 0.011 \mathrm{~kg}$ olarak belirlenmiştir. Toplam tüketilen mama, kaba ve kesif yem miktarları muamele gruplarına göre sirasıyla; $327.7 \pm 42.17$, $331.0 \pm 49.40$ litre; $13.25 \pm 3.025,15.23 \pm 3.682 \mathrm{~kg}$ ve $19.97 \pm 4.186,22.37 \pm 5.709 \mathrm{~kg}$ olarak hesaplanmıştır. Buzağıların kaba ve kesif yem tüketimine başlama yaşları ile ishalli geçirdikleri gün sayısı ise sırasıyla; $10.6 \pm$ $0.29,9.5 \pm 0.28$ gün ve $3.1 \pm 0.111$ ve $1.9 \pm 0.073$ gün olarak tespit edilmiştir. Buzağıların kaba ve kesif yeme başlama yaşları benzer gerçekleşmiştir. Araştırma sonuçları, mamaya ilave edilen kekik yağının buzağılarda uygun dozunun ayarlanması amacıyla daha çok araştırma yapılması gerektiğini ortaya koymuştur.

\section{Araştırma Makalesi}

Makale Tarihçesi

Geliş Tarihi : 01.04.2019

Kabul Tarihi : 16.05 .2019

Anahtar Kelimeler
Buzağı maması
kekik yağı
gelişim
performans
kan
ishal

To Cite : Selvi MH, Tapkı İ 2019. The Effects of Oregano Oil (Origanum onites L.) on the Growth Performance and Some Blood Parameters of Holstein Friesian Calves. KSU J. Agric Nat 22(6): 935-941. DOI: 10.18016/ksutarimdoga.vi.547528. 


\section{INTRODUCTION}

In cases where the prices of raw milk are high and the number of calves are higher, dairy cattle farms can be given milk replacer after drinking colostrum for the first 3 days. Milk replacer are mainly obtained by drying milk and milk products with special processes. In addition to milk and milk products, various plant sources are used to obtain milk replacer. Although calves fed with milk replacer have a lower body weight gain than calves fed with normal milk, this difference closes with compensatory growth after the weaning. Milk replacer should be taken at body temperature and be sure of their quality. Cold drinking or poor quality calf foods can lead to diarrhea and development disorders (Türkmen, 2011; Akyüz et al., 2017). The case of diarrhea caused by infection or feeding is defined as the loss of too much liquid and mineral in the body due to the deterioration of normal fluid movement in the digestive tract. Diarrhea can cause the loss of the body weight with excessive fluid loss by disrupting the chemistry of the body, causing loss of developmental performance and death in more advanced cases (Costello, 2005). The high level of loss of calves both endangers the future of breeding herds and reduces the amount of milk and meat to be obtained from cattle and causes enormous economic losses of the enterprises. In the neonatal period, calf loss is between $1 \%$ and $10 \%$ in developed countries, while this rate can reach up to $10 \%$ and $15 \%$ level in Turkey (Civelek, 2018). In the neonatal period, $60 \%$ and $62.5 \%$ of calf deaths are caused from diarrhea. Calves are very sensitive and vulnerable in the first month after birth and they are faced with many types of harmful bacteria threat. Pathogenic bacteria such as Escherichia coli, Salmonella spp., and Campylobacter spp. cause diarrhea in calves, and in more severe cases, it may result in coccidiosis and death (Tüzemen and Yanar, 2013; Akyüz et al., 2017). Albeit cattle breeders take numerous measures to prevent calf deaths, pathogenic bacteria are abundant in digestive systems in the early days of calves and diarrhea cases persist and calf deaths cannot be fully prevented (Tüzemen and Yanar, 2013). Due to the widespread use of antibiotic feed additives in recent years, the resistance of human and animal pathogens has increased as result of renewing and improving themselves. These pathogens have passed on to humans by leaving residues in animal products, and it has been a concern that antibiotics used for the treatment of these diseases do not work. Due to these concerns, antibiotics were banned in Sweden in 1986 and later in 2005 in EU countries as a feed additive which promotes growth in animal nutrition (Ünlü and Erkek, 2013). The use of antibiotics as a growth factor in animal feed was prohibited in Turkey in January 1, 2006. Due to the antibacterial and antifungal effects of oregano oil, carvacrol and thymol have a lethal effect on microorganisms such as Erwinia amylovara, Bacillus subtilis, Escherichia coli, Hafnia alvei, Micrococcus luteus, Proteus vulgaris, Staphylococcus aureus and Streptococcus faecalis (Souza et al., 2007). Furthermore, due to the effect of essential oils on the intestinal microflora, there are many studies that report feed and daily body weight gain increase and prevent diarrhea and some diseases (Busquet et al., 2006; Calsamiglia et al., 2007; Jouany and Morgavi, 2007; Rusenova and Paronova, 2009; Uetaka, 2013; Ünlü and Erkek, 2013). The aim of this study was to determine the effect of the dietary addition of oregano oil (Origanum onites L.) on growth performance, blood parameters and diarrhea of calves in order to increase the operating income of high milk prices in neonatal life.

\section{MATERIAL and METHODS}

This study was conducted in a private dairy cattle farm in Akcurun district of Antakya, Hatay province. In the study, total 44 of Holstein Friesian calves (24 males, 20 females) were allocated into two groups. All calves were born from the primiparous cows that imported from Hungary. After calving, calves were allowed to stay for 8 hours with their mothers. At the end of this period, calves were taken to individual calf pens and 5 liters colostrum was given for consecutive three days in the morning and evening. From the fourth day on, liquid milk replacer were given to the calves. The milk replacer contained lactoferrin, lactoperoxidase, prebiotics, organic acids, organic selenium, sorbitol, choline and methionine. While the first group (n: 21) was given only milk replacer (n: 23), the second group of calves were given $893 \mathrm{mg}$ oregano oil in addition to milk replacer. Milk replacer was prepared by adding per $\mathrm{kg}$ of powdered milk replacer to 8 liters of water. Liquid milk replacer was given to the calves at 35.5$36.5^{\circ} \mathrm{C}$ temperature twice a day (morning-evening). The amount of milk replacer to be given to the calves was calculated as $10 \%$ of the weekly live weight of the calves. Quality alfalfa and calf starter were given to the calves as ad libitum after the 4 th dayCalf starter consists of $30 \%$ barley, $20 \%$ corn, $10 \%$ wheat bran, $25 \%$ soybean meal, $5 \%$ cottonseed meal, $8 \%$ molasses and $2 \%$ vitamin-mineral mixture, the amount of protein was $196 \mathrm{~g} / \mathrm{kg}$ and the amount of crude fiber was 53 $\mathrm{g} / \mathrm{kg}$. Each $\mathrm{kg}$ alfalfa hay contained as $850 \mathrm{~g} / \mathrm{kg}$ of dry matter, $1530 \mathrm{kcal} / \mathrm{kg}$ metabolizabl energy, $150 \mathrm{~g} / \mathrm{kg}$ crude protein and $290 \mathrm{~g} / \mathrm{kg}$ of crude cellulose. Clean and fresh water at $20-22^{\circ} \mathrm{C}$ temperature was provided in front of the calves for 24 hours. Calves were weaned when they consumed 800 g/day of concentrate feed for three consecutive days. Oregano oil used in the study was obtained from a commercial enterprise and content analyzes were determined by Hewlett Packard 6890 model gas chromatography in Hatay Mustafa Kemal University Central Laboratory. In this study, 
the growth performance characteristics of calves such as daily live weight gain, the amounts of daily hay and concentrated feed consumption, feed conversion ratio, weaning age, weaning weight, total milk replacer consumption and fecal scores were emphasized. In addition a fecal scoring was performed according to Larson et al. (1977). In fecal scoring, normal consistency was evaluated as 1 point; soft but could not be handled was 2 points, easily and easily dispersible was 3 points and no solids in the consistency was evaluated as 4 points. Blood samples from calves were collected from the vena jugularis by the veterinarian, giving importance to the necessary hygiene and cleanliness with the decision of the Board of Ethics Committee No. 2014-8 / 1 of the Animal Experiments Local Ethics Committee of Hatay Mustafa Kemal University. Albumin, AST (SGOT), phosphorus, GGT, glucose, calcium, creatinine, cholesterol, triglyceride, total T3 and T4, globulin, insulin and growth hormone (growth hormone) levels of blood samples were analyzed. The analyzes were carried out in a commercial laboratory with procurement of services. Colorimetric method was used for albumin, creatinine, cholesterol and globulin analyzes; Kinetic method was used for AST (Aspartate aminotransferase) and G-GT (Gamma Glutamyl Transferase); Radioimmunoassay method was used for insulin, total T3 and T4 levels; ELISA (Enzyme Linked Immunosorbent Assay) method was used for the growth hormone (GH) analysis; Glycerol Phosphate Dehydrogenase method was used for triglyceride analysis; flame photometer method was used in calcium analysis and the inorganic phosphate method was used for phosphorus analysis (Karagül et al., 2000). In this study, SPSS (2015) package program was used for the statistical analysis. While General Linear Model "REPEATED MEASURES" test used for weekly live weights and weaning weights, General Linear Model "UNIVARIATE" test was used for daily live weight gain, feed intakes, age of weaning ages, ages of initial consuming hay and concentrate feed, fecal scores, blood parameters and number of days with diarrhea characteristics of calves.

\section{RESULTS and DISCUSSION}

Live Weights, Initial Hay and Concentrate Feed Consuming Ages of Calves

Birth weights, weekly live weights and weaning weights, weaning ages, initial consumption ages of hay and calf starter, daily live weight and total body weight gains of calves are shown in Table 1 and Figure 1 . The oregano oil has a positive effect on all growth performance characteristics of calves. The differences between control and oregano oil used groups for the initial consumption ages of hay and concentrate feed were found statistically significant $(\mathrm{P}<0.05)$, while other characteristics were not found significant $(\mathrm{P}>0.05)$. Calves used Oregano oil have earlier weaning age, higher daily live weight and total weight gains and weaning weights (Table 1). It was observed that calves used oregano oil consumed more $3.3 \mathrm{~kg}$ milk replacer, $1.98 \mathrm{~kg}$ hay and $2.4 \mathrm{~kg}$ concentrate feed than the control groups. Similar studies were conducted on different animal species (Hernandez et al., 2009; Chaves et al., 2008; Simitzis et al., 2008; Abdel-Wareth et al., 2012; Ionescu et al., 2013; Van der Vliet and Cardozo, 2013; Özalpaydın, 2014; Silper et al., 2014; Cardinali et al., 2015). Oregano oil group began to consume hay and concentrate feed at an earlier age of 1.1 days than control group calves. This due to that the oregano oil may have increased feed consumption and appetite, rumen development and regulated rumen $\mathrm{pH}$ at an earlier age.

The Hay, Concentrate Feed and Milk Replacer Consumption Amounts of Calves

The amounts of milk replacer, feed conversion ratio, hay and concentrate feed consumption of control and oregano oil groups are shown in Table 2. The differences between control and oregano oil groups were not significant $(\mathrm{P}>0.05)$ for the total milk replacer, hay, concentrate feed intake and feed conversion ratio.

Table 1. Growth performance values of group

\begin{tabular}{|l|r|r|r|}
\hline & \multicolumn{2}{|c|}{ Calf Groups } & \\
\cline { 2 - 3 } Characteristics & Control (n=21) & Oregano oil (n=23) & P-values \\
\hline Live weights & & & \\
\hline Birth (kg) & $38.7 \pm 5.24$ & $38.6 \pm 4.27$ & 0.918 \\
Week 3 (kg) & $41.4 \pm 4.53$ & $42.3 \pm 4.75$ & 0.514 \\
Week 6 (kg) & $47.5 \pm 6.80$ & $47.9 \pm 5.26$ & 0.830 \\
Week 9 (kg) & $58.1 \pm 8.27$ & $59.6 \pm 7.95$ & 0.538 \\
Weaning weight (kg) & $61.0 \pm 7.65$ & $63.2 \pm 9.38$ & 0.398 \\
Weaning age (d) & $68.6 \pm 4.45$ & $67.7 \pm 4.62$ & 0.547 \\
Inital consuming ages of hay and concentrate feed (d) & $10.6 \pm 0.29$ & $9.5 \pm 0.28$ & 0.012 \\
Daily live weight gain (kg) & $0.300 \pm 0.09$ & $0.400 \pm 0.11$ & 0.242 \\
Total body weight gain (kg) & $22.3 \pm 6.37$ & $24.7 \pm 8.05$ & 0.289 \\
\hline
\end{tabular}

$\mathrm{P}<0.05$ 


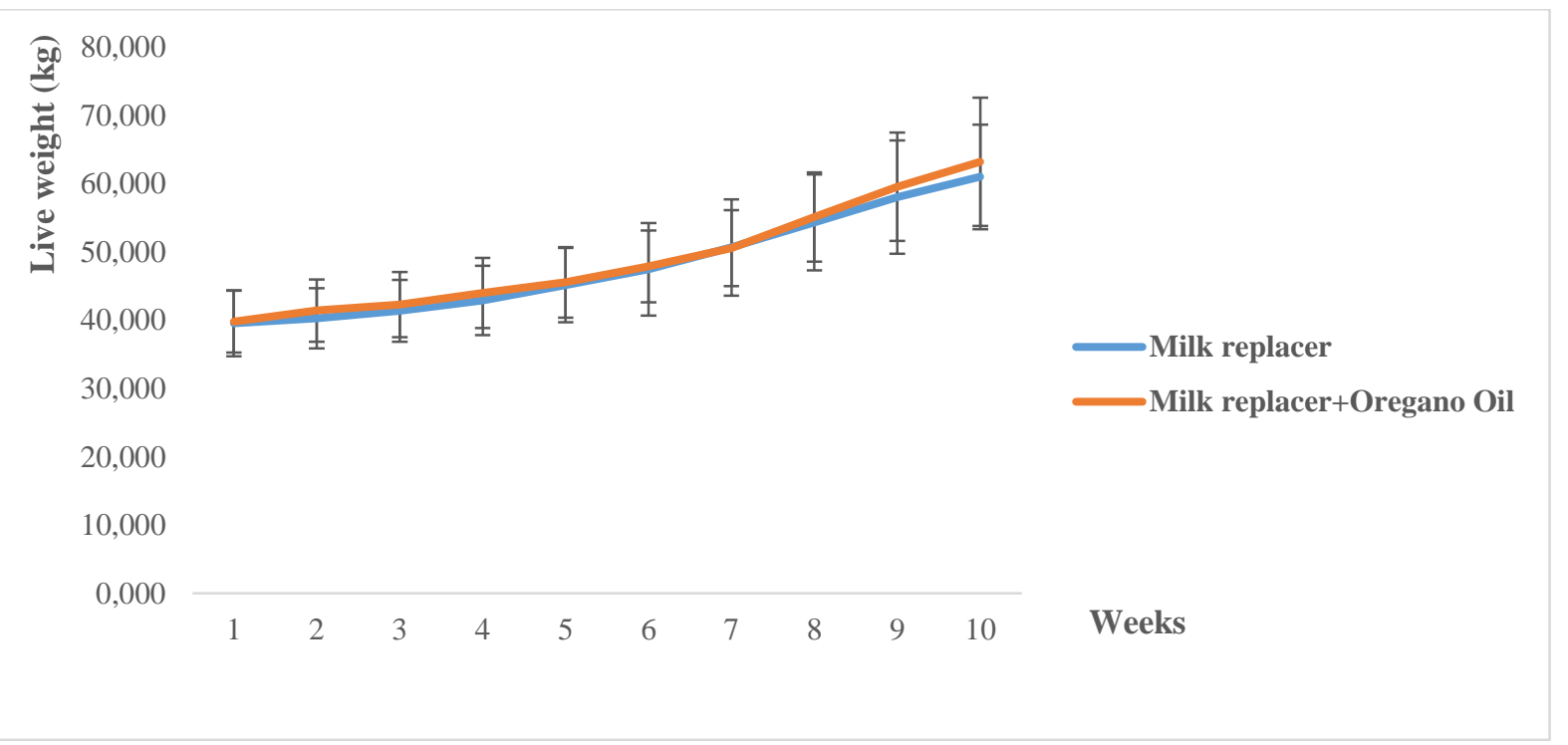

Figure 1. Average weekly live weights of calves (kg)

Table 22 Performance of calves according to measurement time in treatment groups

\begin{tabular}{|c|c|c|c|}
\hline \multirow[b]{2}{*}{ Feed Intake (kg) } & \multicolumn{2}{|c|}{ Calf Groups } & \multirow[b]{2}{*}{$\begin{array}{c}\text { P- } \\
\text { values }\end{array}$} \\
\hline & $\begin{array}{l}\text { Control } \\
(n=21)\end{array}$ & $\begin{array}{l}\text { Oregano oil } \\
(n=23)\end{array}$ & \\
\hline Milk Replacer & \multicolumn{3}{|c|}{ Live weights, kg/calf } \\
\hline Week 3 & $29.0 \pm 3.17$ & $29.6 \pm 3.33$ & 0.663 \\
\hline Week 6 & $33.2 \pm 4.76$ & $33.5 \pm 3.68$ & 0.962 \\
\hline Week 9 & $74.5 \pm 27.45$ & $73.2 \pm 35.35$ & 0.538 \\
\hline At the weaning & $33.8 \pm 26.78$ & $32.6 \pm 31.89$ & 0.398 \\
\hline Total intake & $327.7 \pm 42.17$ & $331.0 \pm 49.40$ & 0.815 \\
\hline Alfalfa Hay & \multicolumn{3}{|c|}{ Feed intakes, kg } \\
\hline Week 3 & $0.17 \pm 0.053$ & $0.20 \pm 0.067$ & 0.262 \\
\hline Week 6 & $1.21 \pm 0.330$ & $1.53 \pm 0.466$ & 0.703 \\
\hline Week 9 & $2.80 \pm 0.512$ & $3.44 \pm 0.645$ & 0.589 \\
\hline At the weaning & $3.43 \pm 0.462$ & $3.60 \pm 0.573$ & 0.537 \\
\hline Total comsumption & $13.25 \pm 3.025$ & $15.23 \pm 3.682$ & 0.881 \\
\hline Daily intake & $0.200 \pm 0.075$ & $0.220 \pm 0.062$ & 0.196 \\
\hline Calf Starter & \multicolumn{3}{|c|}{ Calf starter intakes, kg } \\
\hline Week 3 & $0.14 \pm 0.051$ & $0.18 \pm 0.062$ & 0.685 \\
\hline Week 6 & $1.09 \pm 0.408$ & $1.59 \pm 0.723$ & 0.395 \\
\hline Week 9 & $5.32 \pm 0.986$ & $5.53 \pm 1.264$ & 0.425 \\
\hline At the weaning & $4.52 \pm 1.020$ & $4.62 \pm 1.004$ & 0.387 \\
\hline Total intake & $19.97 \pm 4.186$ & $22.37 \pm 5.709$ & 0.164 \\
\hline Daily intake & $0.290 \pm 0.088$ & $0.330 \pm 0.104$ & 0.225 \\
\hline Feed conversion ratio ( $\mathrm{g}$ feed/g gain) & $3.1 \pm 0.16$ & $2.8 \pm 0.16$ & 0.346 \\
\hline
\end{tabular}

\section{$\mathrm{P}<0.05$}

It was observed that oregano oil group calves consumed more $3.3 \mathrm{~kg}$ milk replacer, $1.98 \mathrm{~kg}$ hay and $2.4 \mathrm{~kg}$ concentrate feed than the control group (Table 2). Similar results were reported by Morrison et al. (2010), Ünlü and Erkek, (2013), Özalpaydin, (2014), Silper et al. (2014), and Seifzadeh et al. (2017), while Santos et al. (2015) stated that oregano oil decreased the amount of consumption of milk replacer.

These differences can be thought to be caused by the fact that essential oils are given to animals in different doses. Because calves initially do not like the taste of essential oils, feed intake was lower. The oregano oil group calves consumed $1.98 \mathrm{~kg}$ more hay than the control group calves. These results can be explained that the oregano oil caused increasing feed consumption due to the positive effect of the calves on the rumen microflora, digestive system and the increasing appetite of calves. Many studies conducted in this subject support the results of current research (Montoro et al., 2011; Vakili et al., 2013; Seifzadeh et 
al., 2017). The calves used oregano oil was consumed $2.40 \mathrm{~kg}$ more concentrate feed than the control group calves (Table 2). These results are similar to Ünlü \& Erkek (2013), and İzzaddeen \& Kaygisız (2018). These results indicated that oregano oil increases calves' appetite and concentrate feed consumption, and starts consuming at earlier ages. However, some studies emphasized that essential oils reduce the number of proteolytic rumen bacteria and decrease the rumen deamination and thus reduce the consumption of concentrate feed (Santos et al. (2015). It may be stated that the differences between studies are based on use of different animal species and essential oils, use of essential oils in different doses and forms and feeding methods. The feed conversion ratio was better in oregano oil group calves (Table 2).

\section{Fecal Scores and Diarrhea Incidence of Calves}

The diarrhea days, fecal scores of calves and the results of statistical analysis are given in Table 3 . The differences between control and oregano oil groups for the diarrhea days and the fecal scores were not statistically significant $(\mathrm{P}>0.05)$. Oregano oil group calves had 1.2 diarrhea days less than control group.

Table 3 Day and fecal scores for diarrhea according to measurement time in treatment groups

\begin{tabular}{|l|c|c|c|}
\hline \multirow{2}{*}{ Diarrhea days (d) } & \multicolumn{2}{|c|}{ Groups } & \multirow{2}{*}{ P-values } \\
\cline { 2 - 4 } & Control (n=21) & Oregano oil(n=23) & 0.124 \\
Week 3 & $0.9 \pm 0.39$ & $0.2 \pm 0.15$ & 0.159 \\
Week 6 & $0.1 \pm 0.10$ & $0.0 \pm 0.00$ & - \\
At the weaning & $0.0 \pm 0.00$ & $0.0 \pm 0.00$ & - \\
Total number of diarrhea days (d) & $0.0 \pm 0.00$ & $0.0 \pm 0.00$ & 0.370 \\
Average of diarrhea days (d) & $3.1 \pm 0.11$ & $1.9 \pm 0.07$ & 0.134 \\
\hline Fecal Scores & $0.3 \pm 0.01$ & $0.2 \pm 0.08$ & 0.211 \\
Week 3 & & & 0.422 \\
Week 6 & $1.57 \pm 0.098$ & $1.26 \pm 0.062$ & 0.301 \\
Week 9 & $1.29 \pm 0.078$ & $1.13 \pm 0.046$ & 0.286 \\
At the weaning & $1.06 \pm 0.038$ & $1.00 \pm 0.000$ & 0.313 \\
Average of fecal score & $1.05 \pm 0.022$ & $1.00 \pm 0.000$ & \\
\hline
\end{tabular}

\section{$\mathrm{P}<0.05$}

This result can be explained by decreasing the activities of the harmful microorganisms which cause diarrhea by regulation of the rumen metabolism of the animals and increasing the rate of feed utilization. These results agree with Bambidis (2006); Ünlü and Erkek, (2013); Özalpaydın (2014); Ammar et al.,
(2017); Seifzadeh et al., (2017) and Katsoulos et al. (2017).

\section{Blood Parameters of Calves}

The results of the statistical analysis of the blood parameters of the calf groups are shown in Table 4.

Table 4 Blood analysis according to the measurement time in treatment groups

\begin{tabular}{|l|r|r|c|}
\hline \multirow{2}{*}{ Blood Parameters } & \multicolumn{2}{|c|}{ Calf' Groups } & \\
\cline { 2 - 3 } & \multicolumn{1}{|c|}{ Control (n=21) } & Oregano oil (n=23) & P-values \\
\hline Albumin (g/dL) & $3.3 \pm 0.11$ & $3.1 \pm 0.07$ & 0.172 \\
AST (U/L) & $108.5 \pm 8.55$ & $86.5 \pm 2.62$ & 0.006 \\
Phosphorus (mg/Dl) & $8.1 \pm 0.64$ & $8.4 \pm 0.28$ & 0.603 \\
G-GT (U/L) & $17.4 \pm 1.59$ & $23.9 \pm 2.50$ & 0.086 \\
Glucose (mg/dL) & $92.5 \pm 8.10$ & $97.0 \pm 6.55$ & 0.680 \\
Calcium (mg/dL) & $9.9 \pm 0.30$ & $10.8 \pm 0.19$ & 0.010 \\
Creatinine (mg/dL) & $0.9 \pm 0.05$ & $0.91 \pm 0.04$ & 0.831 \\
Cholesterol (mg/dL) & $101.1 \pm 5.94$ & $126.6 \pm 12.93$ & 0.181 \\
Triacylglceride (mg/dL) & $31.6 \pm 3.25$ & $36.9 \pm 2.30$ & 0.193 \\
T4 (nmol/L) & $68.6 \pm 11.14$ & $73.8 \pm 6.91$ & 0.679 \\
Globulin (g/dL) & $3.3 \pm 0.20$ & $3.4 \pm 0.16$ & 0.518 \\
T3 (nmol/L) & $2.0 \pm 0.37$ & $1.6 \pm 0.21$ & 0.273 \\
Insulin (pmol/L) & $114.9 \pm 17.10$ & $121.6 \pm 11.78$ & 0.747 \\
GH (ng/mL) & $6.6 \pm 0.30$ & $6.0 \pm 0.33$ & 0.232 \\
\hline
\end{tabular}

$\mathrm{P}<0.05$ 
The differences between control and added oregano oil calves for the AST and calcium were found significant $(\mathrm{P}<0.05)$, while the differences in all other blood parameters were not found significant $(\mathrm{P}>0.05)$. The phosphorus, glucose and triglyceride were not found within normal level range. The level of calcium in the blood was found to be higher in oregano oil added milk fed calves than the control group calves. It can be expressed that oregano oil increases the amount of calcium in the blood as a result of accelerating the absorption of calcium in the small intestine. These results were similar to Karagül et al. (2000) reports.

\section{CONCLUSION}

The results of the study showed that the addition of oregano oil to milk replacer was less important for calves for initializing of consuming hay and concentrated feed. In this study, it has been shown that it was effective in decreasing the age of onset of consumption of coarse and concentrated feed. In the present study, only one dose of oregano oil was used in calves. Since there have been not sufficient studies on the use of essential oils on calves, new studies are required for the effect of different doses and delivery times of essential oils of different plants.

\section{ACKNOWLEDGEMENT}

We thank to Hatay Mustafa Kemal University, Scientific Research Projects Department (BAP) for their support (Project Number:12760)

\section{REFERENCES}

Abdel-Wareth AAA, Kehraus S, Hippenstiel F, Südekum KH, 2012. Effects of thyme and oregano on growth performance of broilers from 4 to 42 days of age and on microbial counts in crop, small intestine and caecum of 42 -day-old broilers. Animal Feed Science and Technology, 178(3): 198-202.

Akyüz E, Naseri A, Erkılıç EE, Makav M, Uzlu E, Kırmızıgül AH, Gokce G, 2017. Neonatal Calves and Sepsis. Kafkas University, Journal of the Institute of Science and Technology, 10 (2): 181-191.

Ammar SSM, Mokhtaria K, Tahar BB, Amar AA, Redha BA, Yuva B, Laid B, (2014). Prevalence of rotavirus (GARV) and coronavirus (BCoV) associated with neonatal diarrhea in calves in western Algeria. Asian Pacific Journal of Tropical Biomedicine, 4(1): 318-322.

Bampidis VA, Christodoulou V, Florou- Paneri P, Christaki E, 2006. Effect of dried Oregano leaves versus neomycin in treating newborn calves with colibacillosis. Journal of Veterinary Medicine Series A, 53(3): 154-156.

Busquet M, Calsamiglia S, Ferret A, Kamel C, 2006. Plant extracts affect in vitro rumen microbial fermentation. Journal of Dairy Science, 89(2): 76177.

Calsamiglia S, Busquet M, Cardozo PW, Castillejos L, Ferret A, Fandiño I, 2007. Essential oils for modifying rumen fermentation: A review, Journal Dairy Science, 90(6): 2580-2595.

Cardinali R, Cullere M, Dal Bosco A, Mugnai C, Ruggeri S, Mattioli S, Dalle Zotte A, 2015. Oregano, rosemary and vitamin $\mathrm{E}$ dietary supplementation in growing rabbits: Effect on growth performance, carcass traits, bone development and meat chemical composition. Livestock Science, 175: 83-89.

Chaves AV, Stanford K, Gibson LL, McAllister TA, Benchaar C, 2008. Effects of carvacrol and cinnamaldehyde on intake, rumen fermentation, growth performance, and carcass characteristics of gowing lambs. Animal Feed Science and Technology, 145(1): 396-408.

Civelek T, 2018. Calf losses are a serious problem for our country. http://www.tarimpusulasi.com/ yazarlar/prof-dr-turan-civelek/buzagi-kayiplariulkemiz-icin-ciddi-bir-sorun/163. Accessed on: 25.02.2018

Costello R, 2005. Calf scours-Causative agents of calfhood diarrhea. A. Division of. Merrick. Animal.Nutrition,. Inc. www.merricks.com. Accessed on: 27.02.2018

Hernandez F, Madrid J, Garcia V, Orengo J, Megias MD, 2004. Influence of two Plant extracts on broilers performance, digestibility and digestive organ size. Poultry Science, 83(2): 169-174.

Hernández J, Benedito JL, Vázquez P, Pereira V, Méndez J, Sotillo J, Castillo C, 2009. Supplementation with plant extracts (carvacrol, cinnamaldehyde and capsaicin): its effects on acidbase status and productive performance in growing/finishing bull calves. Berliner und Munchener Tierarztliche Wochenschrift, 122(3-4): 93-99.

Ionescu C, Mazuranok L, Timmler R, 2013. Effects of combination of carvacrol, cinnamaldehyde and Capsicum oleoresin (XTRACTTM 6930) on the performances of broiler chickens. http://www.bsas.org.uk/wp-content/themes/bsas/ proceedings/Pdf2004/149.pdf. Accessed on: 25 Mayıs 2018.

Izzaddeen SI, Kaygisız A, 2018. Effect of Essential Oil of Laurel (Laurus nobilis L.) on Performance, Blood and Fecal Parameters of Holstein Calves during Suckling Period. Pakistan Journal of Zoology, 50(3): 799-1198.

Jouany JP, Morgavi DP, 2007. Use of 'natural' products as alternatives to antibiotic feed additives in ruminant production. Animal, 1(10): 1443-1466.

Karagül H, Altıntaş A, Fidancı UR, Sel T, 2000. Clinical Biochemistry, Ankara Medisan Publication Series: 45, 1st Edition. 
Katsoulos PD, Karatzia MA, Dovas CI, Filioussis G, Papadopoulos E, Kiossis E, Karatzias H, (2017). Evaluation of the in-field efficacy of oregano essential oil administration on the control of neonatal diarrhea syndrome in calves. Research in Veterinary Science, 115: 478-483.

Larson LL, Owen FG, Albright JL, Appleman RD, Lamb RC, Muller LD, 1977. Guidelines toward more uniformity in measuring and reporting calf experimental data. Journal of Dairy Science, 60(6): 989-991.

Montoro C, Ipharraguerre I, Bach A, 2011 Effect of flavoring a starter in a same manner as a milk replacer on intake and performance of calves. Animal Feed Science and Technology, 164(1): 130134.

Morrison SJ, Dawson S, Carson AF, 2010. The effects of manan oligosaccharide and streptococcus faecium addition to milk replacer on calf health and performance. Livestock Science, 131(2-3): 292-296.

Özalpaydin HB, 2014. The effect of using oregano oil (Origanum onites) on the growth performance of milk-drinking black calf calves. Mustafa Kemal University Graduate School of Natural and Applied Sciences Master Thesis, 44 p, Hatay, Turkey.

Rusenova N, Paronova P, 2009. Antimicrobial activities of twelve essential oils against Microorganisms of veterinary importance. Trakia Journal of Science: 7(1): 37-43.

Santos FHR, De Paula MR, Lezier D, Silva JT, Santos G, Bittar CMM, (2015). Essential oils for dairy calves: effects on performance, scours, rumen fermentation and intestinal fauna. Animal, 9(6): 958-965.

Seifzadeh S, Mirzaei Aghjehgheshlagh F, Abdibenemar H, Seifdavati J, Navidshad B, 2017. The effects of a medical plant mix and probiotic on performance and health status of suckling Holstein calves. Italian Journal of Animal Science, 16(1): 4451.

Silper BF, Lana AMQ, Carvalho AU, Ferreira CS, Franzoni APS, Lima JAM, Coelho SG, 2014. Effects of milk replacer feeding strategies on performance, ruminal development, and metabolism of dairy calves. Journal of Dairy Science, 97(2): 1016-1025.

Simitzis PE, Deligeorgis SG, Bizelis JA, Dardamani A, Theodosiou I, Fegeros K, 2008. Effect of dietary oregano oil supplementation on lamb meat characteristics. Meat Science, 79(2): 217-223.

Souza EL, Stamford TLM, Lima EO, Trajano VN, 2007. Effectiveness of Origanum vulgare L. essential oil to inhibit the growth of food spoiling yeasts. Food Control, 18: 409-413.

Uetake K, 2013. Newborn calf welfare: A review focusing on mortality rates. Animal Science Journal, 84: 101-105.

Tüzemen N, Yanar M, 2013. Calf Breeding Techniques. Erzurum, Atatürk University Faculty of Agriculture Course Publications No: 232, Erzurum, Turkey.

Ünlü HB, Erkek R, 2013. Effects of Thyme and Garlic Essential Oil on Calf Performance and Some Blood Parameters. Ege University, Journal of Agriculture Faculty, 50(3): 299-310.

Vakili AR, Khorrami B, Mesgaran MD, Parand E, 2013. The effects of thyme and cinnamon essential oils on performance, rumen fermentation and blood metabolites in Holstein calves consuming high concentrate diet. Asian-Australasian Journal of Animal Sciences, 26(7): 935-944.

Van der Vliet H, Cardozo PW, 2013. Head-start strategies for optimal calf rearing. International Dairy Topics, 7 (5):13-15. http://www. positiveaction.info/pdfs/articles/dt7.5p13. Accessed on: 20 Haziran 2018. 